J. Dairy Sci. 99:8759-8778

http://dx.doi.org/10.3168/jds.2016-11371

(C) 2016, THE AUTHORS. Published by FASS and Elsevier Inc. on behalf

of the American Dairy Science Association ${ }^{\circledR}$. This is an open access article under

the CC BY-NC-ND license (http://creativecommons.org/licenses/by-nc-nd/3.0/).

\title{
The influence of dietary nitrogen reduction and conjugated linoleic acid supply to dairy cows on fatty acids in milk and their transfer to ripened cheese
}

\section{S. Schiavon, G. Cesaro, ${ }^{1}$ A. Cecchinato, C. Cipolat-Gotet, F. Tagliapietra, and G. Bittante \\ Department of Agronomy, Food, Natural Resources, Animals and Environment (DAFNAE), University of Padua, Viale dell'Università 16, 35020 Legnaro (PD), Italy}

\begin{abstract}
The aim of this study was to investigate the consequences of reducing the dietary crude protein content, with or without a supply of protected conjugated linoleic acid (CLA), on the milk fatty acid (FA) yield and recovery in $90 \mathrm{~d}$ ripened cheese. Twenty mid-lactation Friesian dairy cows were reared for 4 periods of $3 \mathrm{wk}$ each in groups of 5 , following a $4 \times 4$ Latin square design. Cows were fed 4 different rations, consisting of a combination of the 2 dietary crude protein levels [150 (CP15) or 123 (CP12) g of crude protein $/ \mathrm{kg}$ of dry matter], with or without a conjugated linoleic acid supply $(80 \mathrm{~g} / \mathrm{d}$, providing 5.57 and $5.40 \mathrm{~g} / \mathrm{d}$ of C18:2 cis-9,trans-11 and C18:2 trans-10,cis-12, respectively). Milk yield was recorded. Twice in each period, milk samples were analyzed for protein, fat, and lactose content, and $10 \mathrm{~L}$ milk samples (pooled by group) were processed to produce 96 cheeses, which were ripened for $90 \mathrm{~d}$. Milk and cheese fat were analyzed for their FA profiles. Milk and cheese FA were expressed as daily yields and relative proportions, and nutrient recoveries were computed. Dietary crude protein reduction had small or no effects on the yield and relative presence of FA in milk and cheese, except for a small increase in mid-chain branched saturated fatty acids. The CLA supply strongly reduced the yield of various categories of FA, and had major effects on short-chain FA of de novo synthesis, leading to changes in the relative proportions of the various FA in milk and cheese. The addition of CLA tended to reduce uniformly the recovery of all milk constituents and of short-, medium-, and long-chain FA groups, but we observed large differences among individual FA with apparent recoveries ranging between 640 and $1,710 \mathrm{~g} / \mathrm{kg}$. The highest recoveries were found for polyunsaturated long-chain FA, the lowest for saturated or monounsaturated short- or medium-chain
\end{abstract}

Received April 27, 2016.

Accepted July 7, 2016

${ }^{1}$ Corresponding author: giacomo.cesaro@unipd.it
FA. A notable rearrangement of these FA components, particularly the minor ones, took place during ripening. Key words: conjugated linoleic acid, dietary protein, fatty acid, milk, cheese

\section{INTRODUCTION}

Reducing the environmental impact of animal farming and producing milk and cheese with improved nutritional characteristics are among the most important challenges for our dairy industry today. Feeding dairy cows excess protein contributes to environmental $\mathrm{N}$ pollution and could lead to unnecessary feeding expenditure due to the high costs of protein sources (Kebreab et al., 2002), but the use of low-protein rations as a means of reducing $\mathrm{N}$ loss in the environment could cause changes in the nutritional and technological characteristics of milk. Cesaro and Schiavon (2015) showed that $\mathrm{CP}$ restriction influenced the coagulation, curd firmness, and syneresis of Holstein-Friesian milk. Leonardi et al. (2003) and Cabrita et al. (2007) reported that a reduction in dietary $\mathrm{CP}$ content caused some alteration to the milk fatty acid (FA) profile: a decrease in the proportion of medium-chain FA (C16:0), and an increase in C18:1 trans isomers and some CLA isomers. An increase in the milk fat content of these trans-octadecenoic isomers and related metabolites, such as CLA isomers, has been frequently associated with milk fat depression (Griinari et al., 1998; Bauman et al., 2008; Shingfield et al., 2010). The use of a commercial rumen-protected CLA mixture has also consistently been found to considerably reduce the milk FA yield and profile (Perfield et al., 2002). Because dietary CP reduction has been related to an increase in these bioactive milk FA (Cabrita et al., 2007), it is possible that dietary protein and CLA supplementation interact with respect to milk FA composition and FA yield.

The proportion of milk processed into cheese is growing worldwide (IDF, 2015), and there is interest in assessing the effects of different feeding treatments on 
cheese quality (Colombari et al., 2001; Angulo et al., 2012) including the FA profile of milk and the derived cheese and the pathways of FA transfer from milk to cheese. Some authors have suggested that the FA profile of fresh cheese reflects that of the milk from which it has been made (Allred et al., 2006; Bodkowski et al., 2016); others (Mordenti et al., 2015; Bocquel et al., 2016) have suggested that alterations to the FA profile probably occur during ripening. However, few studies have specifically addressed the transfer of individual FA from milk to cheese (Cattani et al., 2014).

The aim of this work was to study the effect of conventional or low-protein diets, with or without CLA supplement, on milk and cheese individual FA yields and proportions, and to investigate the effect of cheese manufacturing and ripening on individual FA recoveries in cheese.

\section{MATERIALS AND METHODS}

All experimental procedures involving animals were approved by the Ethical Committee for the Care and Use of Experimental Animals of the University of Padua.

\section{Animals, Diets, Milk Yield, and Composition}

A detailed description of the animal characteristics, diets, experimental design, production performance, and $\mathrm{N}$ balance is given in Schiavon et al. (2015). Briefly, 20 Holstein-Friesian cows with equal milk yield (31.0 \pm $1.4 \mathrm{~kg} / \mathrm{d})$, DIM $(174 \pm 6 \mathrm{~d})$, parity $(2.0 \pm 0.36)$, BW $(641 \pm 26 \mathrm{~kg})$, and BCS $(2.9 \pm 0.07)$ were randomly allotted to groups of 5 animals in 4 pens. The cows were fed once a day on TMR according to a $4 \times 4$ Latin square design, over 4 periods of 3 wk ( 2 for adaptation and 1 for sample collection) and 4 dietary treatments. The sequence of treatments was designed to ensure that each group received rations with low $(\mathbf{C P 1 2})$ or control CP (CP15) contents for 6 consecutive weeks, the rumen-protected CLA was added or withdrawn without a simultaneous change in the $\mathrm{CP}$ content of the diet, and the change in $\mathrm{CP}$ was made without a simultaneous change in CLA status, as illustrated in Schiavon et al. (2015). Control rations were formulated following NRC (2001) recommendations to meet the energy and nutrient requirements for $30.0 \mathrm{~kg} / \mathrm{d}$ of milk yield with 35,34 , and $47 \mathrm{~g} / \mathrm{kg}$ of protein, fat, and lactose, respectively, with a predicted DMI of $21 \mathrm{~kg} / \mathrm{d}$. The $2 \mathrm{CP} 12$ rations were formulated from the ingredient composition of the control rations by replacing soybean meal with barley grain (Table 1). The CP15 and the CP12 rations contained 150 and $123 \mathrm{~g} / \mathrm{kg} \mathrm{DM}$ of $\mathrm{CP}$, respectively. The $\mathrm{CP} 15_{\mathrm{CLA}}$ and CP12 $\mathrm{CLA}$ rations were supplemented with
$80 \mathrm{~g} / \mathrm{d}$ of a top-dressed commercial lipid-coated CLA mixture (Sila, Noale, Italy), as described in Schiavon et al. (2011), to provide about 5.57 and $5.40 \mathrm{~g} / \mathrm{d}$ of cis-9,trans-11 CLA and trans-10,cis-12 CLA isomers, respectively.

Cows were milked twice a day, at 5:00 a.m. and 5:30 p.m., and individual milk yield was recorded at each milking using an automatic milking system for the herringbone parlor coupled with automatic recording software (Alpro; DeLaval, Tumba, Sweden). During the third week of each period, individual milk samples from the morning and evening milkings were analyzed each day for fat, protein, and lactose content using the International Dairy Federation (IDF) procedure (IDF, 2000) and a MilkoScan apparatus (Foss Electric, Hillerød, Denmark). The average computed morning and evening milk fat yields and milk protein yields were very similar: $0.473 \pm 0.153$ and $0.481 \pm 0.174 \mathrm{~kg} / \mathrm{d}$ for fat, and $0.495 \pm 0.113$ and $0.463 \pm 0.102 \mathrm{~kg} / \mathrm{d}$ for protein, respectively, in agreement with our previous observations on the same herd of Holstein-Friesian cows fed corn-silage-based TMR with milking intervals of 12 $\mathrm{h}$. We assumed no differences in FA profile between the milk collected in the morning and evening milkings (Larsen et al., 2012).

On d 2 and 4 of the last week of each experimental period, individual milk samples $(2,100 \mathrm{~mL})$ from the morning milking were collected for analysis, and 2 cheesemaking sessions were held. The milk samples from each cow were pooled by group and poured into 2 laboratory cheese vats (11 L capacity; Pierre Guerin Technologies, Mauze, France). Two aliquots of $50 \mathrm{~mL}$ were sampled from each vat. One aliquot from each was immediately analyzed for fat, protein, and total solids using the MilkoScan apparatus (IDF, 2000); the other was stored at $-80^{\circ} \mathrm{C}$ and later analyzed for milk FA profile using 2-dimensional gas chromatography ( $\mathrm{GC} \times$ GC), according to Pellattiero et al. (2015a).

\section{Cheesemaking and Cheese Composition}

Milk was processed into cheese without preliminary heat or homogenization treatments, and cheese manufacturing was carried out simultaneously for the 4 experimental treatments during each cheesemaking session ( 2 sessions per experimental period, 8 in total, for a grand total of 32 cheesemakings). Cheeses were made according to the same procedure as described in previous studies (Cattani et al., 2014). During each cheesemaking, 3 cheese wheels were produced per vat, for a total of 96 wheels ( 4 groups $\times 4$ periods $\times 2$ sessions $\times 3$ wheels). All wheels were ripened for $90 \mathrm{~d}$ in a cell at $15^{\circ} \mathrm{C}$ and $85 \%$ relative humidity and weighed at regular intervals from d 1 to 90 of ripening (around 200 
$\mathrm{g}$ /wheel initial weight). At the end of ripening, the rind was removed from 1 of the 3 wheels per vat produced in each session, and 4 samples of about $50 \mathrm{~g}$ were milled and stored at $-80^{\circ} \mathrm{C}$ before analysis. After thawing, the samples were analyzed for fat, protein, and total solids using an NIRS-T FoodScan, (Foss Electric) following the International Organization for Standardization (ISO; 21543) and IDF (201) methodology (ISO, 2006) for milk products.

\section{Analysis of Milk and Cheese Fatty Acid Content}

Lipid Extraction. Lipid extraction was performed according to Hara and Radin (1978) and Chouinard et al. (1999) using hexane:isopropanol $(3: 2, \mathrm{vol} / \mathrm{vol})$ as a solvent solution at room temperature. After evaporation of the solvent, the extracted fat was weighed.

Lipid extraction from cheese samples was completed using a Soxtec extraction apparatus (ST 255; Foss Electric). After thawing, samples were processed according to ISO methodology (ISO, 2001). Briefly, $4 \mathrm{~g}$ of cheese was ground using a 1:1 mixture of sand and sodium sulfate to obtain a dry test sample. The test portion was then transferred to an extraction thimble, which was closed with cotton wool and connected to the Soxtec extraction apparatus. The sample was extracted for $6 \mathrm{~h}$ under reflux using $250 \mathrm{~mL}$ of $n$-pentane as a solvent. The excess solvent was then removed by evaporating the contents of the flask under reduced pressure in a water bath at $50^{\circ} \mathrm{C}$ until visually com-

Table 1. Ingredient and chemical composition ( $\mathrm{g} / \mathrm{kg}$ of DM, unless otherwise noted), and fatty acid profile $(\mathrm{g} / \mathrm{d})$ of the experimental rations ${ }^{1}$

\begin{tabular}{|c|c|c|c|c|}
\hline Item & CP15 & $\mathrm{CP} 15_{\mathrm{CLA}}$ & CP12 & $\mathrm{CP} 12_{\mathrm{CLA}}$ \\
\hline \multicolumn{5}{|l|}{ Ration ingredient } \\
\hline Corn silage & 313 & 313 & 309 & 309 \\
\hline Corn grain, ground & 174 & 174 & 172 & 172 \\
\hline Soybean meal (solvent extracted $44 \%$ ) & 63 & 63 & 63 & 63 \\
\hline Meadow hay & 124 & 124 & 121 & 121 \\
\hline Sugar beet pulp, dried & 103 & 103 & 105 & 105 \\
\hline Alfalfa hay & 87 & 87 & 88 & 88 \\
\hline Wheat bran & 54 & 54 & 50 & 50 \\
\hline Vitamin and mineral mixture $^{2}$ & 17 & 17 & 17 & 17 \\
\hline Barley grain, ground & — & - & 75 & 75 \\
\hline Soybean meal (solvent extracted $44 \%$ ) & 65 & 65 & - & - \\
\hline Rumen-protected CLA mixture, g/d & - & 80 & - & 80 \\
\hline \multicolumn{5}{|l|}{ Ration chemical constituents } \\
\hline $\mathrm{CP}^{3}$ & 150 & 150 & 123 & 123 \\
\hline NDF & 369 & 369 & 374 & 374 \\
\hline Starch & 227 & 227 & 263 & 263 \\
\hline Ether extract & 24 & 28 & 24 & 28 \\
\hline \multicolumn{5}{|l|}{ Daily fatty acids allowance ${ }^{4}$} \\
\hline Total fatty acids & 387 & 436 & 387 & 436 \\
\hline SFA & 120 & 153 & 122 & 154 \\
\hline C16:0 & 62.1 & 66.9 & 64.3 & 69.1 \\
\hline C18:0 & 39.8 & 67.1 & 39.5 & 66.7 \\
\hline MUFA & 88.1 & 93.0 & 86.7 & 91.6 \\
\hline C18:1 cis-9 & 67.4 & 72.2 & 66.2 & 70.9 \\
\hline PUFA & 175 & 186 & 175 & 186 \\
\hline C18:2 cis-9,cis-12 & 149 & 150 & 150 & 151 \\
\hline $\mathrm{C} 18: 3$ cis -9, cis -12, cis -15 & 21.3 & 21.3 & 20.7 & 20.7 \\
\hline$\Sigma \mathrm{CLA}$ & 0.56 & 11.5 & 0.56 & 11.5 \\
\hline C18:2 cis-9,trans-11 (CLA) & 0.128 & 5.70 & 0.127 & 5.70 \\
\hline C18:2 trans-10,cis-12 (CLA) & 0.100 & 5.50 & 0.103 & 5.50 \\
\hline
\end{tabular}

${ }^{1} \mathrm{CP} 15$ and $\mathrm{CP} 12=$ diets providing 150 or $123 \mathrm{~g}$ of $\mathrm{CP} / \mathrm{kg}$ of $\mathrm{DM}$, respectively; $\mathrm{CP} 15_{\mathrm{CLA}}$ and $\mathrm{CP} 12_{\mathrm{CLA}}=$ diets top-dressed with $80 \mathrm{~g} / \mathrm{d}$ of a commercial mixture of rumen-protected CLA providing 5.57 and $5.40 \mathrm{~g} / \mathrm{d}$ of C18:2 cis-9,trans-11 and C18:2 trans-10,cis-12, respectively (SILA, Noale, Italy).

${ }^{2}$ Quality Index Complete (Farmer Spa, Porto Mantovano, Mantova, Italy): 240,000 IU/kg vitamin A, $500 \mathrm{mg} /$ $\mathrm{kg}$ vitamin $\mathrm{E}, 80 \mathrm{mg} / \mathrm{kg}$ vitamin $\mathrm{B}_{1}, 0.4 \mathrm{mg} / \mathrm{kg}$ vitamin $\mathrm{B}_{12}, 2,040 \mathrm{mg} / \mathrm{kg}$ niacin, $650 \mathrm{mg} / \mathrm{kg}$ of manganese, 100 $\mathrm{mg}$ of copper (as copper sulfate pentahydrate), $12 \mathrm{mg} / \mathrm{kg}$ of cobalt (as basic cobalt carbonate, monohydrate). ${ }^{3}$ The RDP content was computed from dietary ingredient composition according to the NRC (2001) and was equal to $98,100,81$, and $81 \mathrm{~g} / \mathrm{kg}$ of DM for CP15, CP15 $5_{\text {CLA }}$ CP12, and CP12 $2_{\text {CLA }}$, respectively. The MP content was computed from dietary ingredient composition according to the NRC (2001) and was 103, 102, 83, and 83 $\mathrm{g} / \mathrm{kg}$ of DM for CP15, CP15 $\mathrm{CLA}, \mathrm{CP} 12$, and CP12 $\mathrm{CLA}$, respectively.

${ }^{4}$ Computed assuming a predicted DMI of $21 \mathrm{~kg} / \mathrm{d}$, according to the NRC (2001). 
plete. The sample was flushed under a stream of $\mathrm{N}$ for $1 \mathrm{~min}$, and then connected to the rotary evaporator for another $10 \mathrm{~min}$. Once the solvent had evaporated, the sample was weighed and transferred to culture tubes for transesterification and methylation.

Transesterification and Methylation. The same transesterification and methylation process was used for both milk and cheese fats. About $44 \mathrm{mg}$ of extracted fat was subjected to mild acid-base transesterification and methylation (Jenkins, 2010) to esterify all complex and simple forms of FA, avoiding alterations to CLA and PUFA. Briefly, $2 \mathrm{~mL}$ of sodium methoxide $(0.5 \mathrm{M}$ in methanol) and $2 \mathrm{~mL}$ of toluene containing $2 \mathrm{mg} /$ $\mathrm{mL}$ of methyl 12-tridecenoate as internal standard (U35M; Nu-Chek Prep Inc., Waterville, MN) were added to the sample and the mixture incubated in a $50^{\circ} \mathrm{C}$ water bath for $10 \mathrm{~min}$, and then removed from the bath and cooled for $5 \mathrm{~min}$. After the addition of $3 \mathrm{~mL}$ of freshly prepared methanolic $\mathrm{HCl}(1.37 \mathrm{M})$, the sample was incubated again in an $80^{\circ} \mathrm{C}$ water bath for $10 \mathrm{~min}$, removed from the bath, and cooled for $7 \mathrm{~min}$. Then, 5 $\mathrm{mL}$ of $\mathrm{K}_{2} \mathrm{CO}_{3}(0.43 \mathrm{M})$ and $2 \mathrm{~mL}$ of toluene were added to each tube, and tubes were vortexed for $30 \mathrm{~s}$ and centrifuged for $5 \mathrm{~min}$ at $400 \times \mathrm{g}$ and $4^{\circ} \mathrm{C}$. The organic phase was transferred into a screw-capped tube, and $0.5 \mathrm{~g}$ of anhydrous sodium sulfate and $0.5 \mathrm{~g}$ of active charcoal (Sigma-Aldrich, St. Louis, MO) were added. The FAME solution was vortexed for 5 min and rested for $1 \mathrm{~h}$. After centrifugation for $5 \mathrm{~min}$ at $400 \times g$ and $4^{\circ} \mathrm{C}$, the clear upper layer containing the solution was transferred to a GC vial for analysis.

GC Analysis. The FAME solutions obtained from milk and cheese were analyzed for their FA profiles using a GC $\times$ GC $(7890$ A; Agilent Technologies, Santa Clara, CA) with 2 columns in series, as already described by Cesaro et al. (2013), equipped with a modulator (G3486A; Agilent Technologies), an automatic sampler (7693; Agilent Technologies), and a flame ionization detector connected to a chromatography data system software (ChemStation; Agilent Technologies). This 2-dimensional GC equipment has been found suitable for the accurate separation, identification, and quantification of a large number of $\mathrm{FA}$ in ruminant meat and milk samples (Pellattiero et al., 2015a,b; Schiavon et al., 2016). The operative conditions of the gas chromatography apparatus were as follows: first column of $75 \mathrm{~m} \times 180 \mu \mathrm{m}$ (internal diameter) $\times 0.14 \mu \mathrm{m}$ film thickness (23348U; Supelco, Bellefonte, PA), $\mathrm{H}_{2}$ carrier flow of $0.22 \mathrm{~mL} / \mathrm{min}$; second column of $3.8 \mathrm{~m} \times 250$ $\mu \mathrm{m}$ (internal diameter) $\times 0.25 \mu \mathrm{m}$ film thickness $(\mathrm{J} \& \mathrm{~W}$ 19091-L431; Agilent Technologies), $\mathrm{H}_{2}$ carrier flow of $22 \mathrm{~mL} / \mathrm{min}$. Planned oven temperature variations were from $50^{\circ} \mathrm{C}$ (held for $2 \mathrm{~min}$ ), increased to $150^{\circ} \mathrm{C}$ at a rate of $50^{\circ} \mathrm{C} / \mathrm{min}$ (held for $15 \mathrm{~min}$ ), then increased to $240^{\circ} \mathrm{C}$ at $2^{\circ} \mathrm{C} / \mathrm{min}$ (held for $84 \mathrm{~min}$ ). Valves were as follows: modulation delay, $1 \mathrm{~min}$; modulation period, $2.90 \mathrm{~s}$; sample time, $2.77 \mathrm{~s}$. Gas flows were as follows: hydrogen, $20 \mathrm{~mL} / \mathrm{min}$; air, $450 \mathrm{~mL} / \mathrm{min}$. Sample injection was $0.8 \mu \mathrm{L}$ (pulsed split mode, injection pressure $0.172 \mathrm{MPa} \times 0.3 \mathrm{~min}$, split ratio 150:1).

The resulting 2-dimensional chromatograms were analyzed using comprehensive GC $\times$ GC software (Zoex Corp., Houston, TX) to evaluate the volumes of each FA cone. Fatty acids were identified by comparing the cone position in the chromatogram with the cone position of FA present in $2 \mathrm{GC}$ reference standards (674, 463; Nu-Chek Prep Inc.), which were a mixture of pure FA plus individual CLA isomers [cis-9,trans-11 CLA (UC-60M, Nu-Chek Prep Inc.); trans-10, cis-12 CLA (UC-61M, Nu-Chek Prep Inc); cis-9, cis-11 CLA, trans-9,trans-11 CLA, and cis-11,trans-13 CLA (1256, 1257, 1259, respectively; Matreya LLC, Pleasant Gap, PA)]. Fatty acids not included in these standards were identified by their position in the 2-dimensional GC $\times$ GC chromatogram. Fatty acid methyl esters were quantified using the internal standard technique, and the cone volume of each FA was corrected using flame ionization detector relative response factors (Schiavon et al., 2016). Response factor values were calculated using a calibration obtained from 5 serial dilutions for each standard FA purchased $(1,0.5,0.25,0.125$, and $0.0625)$. All 59 calibration curves were linear, and all $\mathrm{R}^{2}$ values were $>0.997$. Each FA was then quantified as an adjusted volume with respect to the total adjusted volume of all FA (excluding the volume of the internal standard, methyl 12-tridecenoate) in the chromatogram, and was expressed in $\mathrm{mg} / \mathrm{g}$ of total FA, based on the concentration in weight of the methyl 12-tridecenoate in the solution.

Main Fatty Acid Categories. The various FA were summed in the following categories.

- Saturated FA were the sum of C4:0, C6:0, C7:0, C8:0, C9:0, C10:0, C11:0, C12:0, C13:0, C13:0 iso, $\mathrm{C} 13: 0$ anteiso, C14:0, C14:0 iso, C15:0, C15:0 iso, $\mathrm{C} 15: 0$ anteiso, C16:0, C16:0 iso, C17:0, C17:0 iso, $\mathrm{C} 17: 0$ anteiso, C18:0, C18:0 iso, C19:0, C19:0 iso, C19:0 anteiso, C20:0, C21:0, C22:0, and C24:0.

- Even SFA (SFA with a linear carbon chain and an even number of carbons) were the sum of C4:0, C6:0, C8:0, C10:0, C12:0, C14:0, C16:0, C18:0, C20:0, C22:0, and C24:0.

- Odd SFA (SFA with a linear carbon chain and an odd number of carbons) were the sum of C7:0, C9:0, C11:0, C13:0, C15:0, C17:0, C19:0, and C21:0.

- Branched odd SFA (SFA with branched carbon chains) were the sum of $\mathrm{C} 13: 0$ iso, C13:0 anteiso, 
C14:0 iso, C15:0 iso, C15:0 anteiso, C16:0 iso, $\mathrm{C} 17: 0$ iso, C17:0 anteiso, C18:0 iso, C19:0 iso, and $\mathrm{C} 19: 0$ anteiso.

- Monounsaturated FA were the sum of C10:1 cis9, $\Sigma$ C12:1 isomers, C14:1 cis-9, C14:1 trans-9, $\Sigma$ C14:1 others, C15:1 cis-10, C15:1 trans-10, $\Sigma$ C15:1 others, C16:1 cis-9, $\Sigma$ C16:1 isomers, $\Sigma$ C16:1 others, $\Sigma$ C17:1 isomers, C18:1 cis-9, C18:1 cis-11, C18:1 trans-6, C18:1 trans-9, C18:1 trans-10, C18:1 trans-11, $\Sigma$ C19:1 isomers, and $\Sigma$ C20:1 isomers. The sum of unsaturated FA isomers, identified by comparison with the standard position, were indicated as the sum of isomers. The sum of isomers recognized by position were indicated as the sum of others.

- Polyunsaturated FA were the sum of C18:2 cis9,cis-12, C18:3 cis-6,cis-12,cis-15, C18:3 cis-6,cis9,cis-12, C18:4 cis-6,cis-9,cis-12,cis-15, C19:5 cis-5, cis-8, cis-11,cis-14,cis-17, C20:2 cis-11,cis-14, $\mathrm{C} 20: 3 \quad$ cis-8, cis-11,cis-14, C20:4 cis-5, cis-8, cis11,cis-14, C20:4 cis-8,cis-11,cis-14,cis-17, C20:5 cis-5,cis-8,cis-11,cis-14,cis-17, and C22:4 cis7,cis-10,cis-13,cis-16, plus the identified CLA isomers C18:2 cis-9,cis-11, C18:2 cis-10,cis-12, C18:2 cis-9,trans-11, C18:2 cis-11,trans-13, C18:2 trans-9,trans-11, and C18:2 trans-10,cis-12. The sum of the identified CLA isomers was indicated as $\Sigma$ CLA.

\section{Computations}

The milk yield for each group of cows was obtained by averaging the yields achieved during the days of milk collection for cheese processing, different from Schiavon et al. (2015), where milk yield was a weekly mean.

Protein, fat, and lactose yields in milk $(\mathrm{g} / \mathrm{d})$ were calculated on the basis of the daily milk yield of each group of cows over the cheesemaking session and the corresponding protein, fat, and lactose contents of the milk collected from each vat. Total milk FA content was calculated as 0.933 milk fat. After the analysis of 558 milk FA profiles, Glasser et al. (2007) evidenced that this coefficient had a small standard deviation $(0.2 \%)$ and that varying proportions of the different lipid classes in milk fat had a very small effect on this figure. The yield of each FA $(\mathrm{g} / \mathrm{d})$ from each cow was calculated on the basis of the milk fat yield and the FA content of the milk sample collected from each cheese vat, which contained milk from the group of cows.

Daily cheese yield (dCY90, kg/d) per cow was calculated on a pen basis as the ratio between the weight of the cheese wheels produced by each vat ( 3 wheels) after $90 \mathrm{~d}$ of ripening, the weight of the milk processed to cheese, and the average milk yield for the days of milk collection for cheese processing:

$$
\begin{aligned}
& \mathrm{dCY} 90=\text { weight of ripened cheese }(\mathrm{kg}) / \\
& \text { weight of milk }(\mathrm{kg}) \times \text { milk yield }(\mathrm{kg} / \mathrm{d}) .
\end{aligned}
$$

The chemical composition of cheese was used to estimate cheese protein, fat, and TS yields on a daily basis. The recovery of each nutrient, fat, protein, TS, and individual FA was calculated as the ratio between the yield of that nutrient or FA in the cheese and in the milk processed.

\section{Statistical Analysis}

The yields of major nutrients (protein, fat, and TS) in milk or cheese, and the recoveries of major nutrients and FA categories were analyzed using the SAS MIXED procedure (SAS Inst. Inc., Cary, NC) with the following model:

$$
\begin{gathered}
\mathrm{y}_{\mathrm{ijk} l}=\mu+\mathrm{P}_{\mathrm{i}}+\mathrm{G}_{\mathrm{j}}+\mathrm{D}_{\mathrm{k}}+\mathrm{C}_{1}+\mathrm{P} \times \mathrm{C}_{\mathrm{il}} \\
+\mathrm{D} \times \mathrm{P}_{\mathrm{ki}}+\mathrm{D} \times \mathrm{P} \times \mathrm{C}_{\mathrm{kil}}+\mathrm{e}_{\mathrm{ijk} \mathrm{k}},
\end{gathered}
$$

where $y_{i j k l}$ was the dependent variable; $\mu$ was the overall intercept of the model; $\mathrm{P}_{\mathrm{i}}$ was the fixed effect of the ith period $(i=1, \ldots, 4) ; G_{j}$ was the random effect of the $\mathrm{jth}$ group of cows $(\mathrm{j}=1, \ldots, 4) ; \mathrm{D}_{\mathrm{k}}$ was the fixed effect of the kth dietary treatment $(\mathrm{k}=1, \ldots, 4) ; \mathrm{C}_{1}$ was the fixed effect of the lth cheesemaking session within each period $(\mathrm{l}=1,2) ; \mathrm{P} \times \mathrm{C}_{\mathrm{il}}$ was the fixed effect of the ilth interaction between period and cheesemaking session (il $=1, \ldots, 8) ; \mathrm{D} \times \mathrm{P}_{\mathrm{ki}}$ was the random effect of the kith interaction between dietary treatment and period $(\mathrm{ki}=1, \ldots, 16) ; \mathrm{D} \times \mathrm{P} \times \mathrm{C}_{\text {kil }}$ was the random effect of the kilth interaction between dietary treatment, period, and cheesemaking session ( $k i l=1, \ldots, 32)$; and $\mathrm{e}_{\mathrm{ijkl}}$ was the random residual. Group was assumed to be independently and normally distributed with a mean of zero and a variance of $\sigma_{j}^{2}$.

Data on yields or relative contents of milk FA were merged with the corresponding values found for cheese and analyzed with a model similar to the one above, but including type of product as an additional effect $\left(\mathrm{PR}_{\mathrm{m}}\right.$, milk or cheese, $\left.\mathrm{m}=1,2\right)$ and a $\mathrm{PR}_{\mathrm{m}} \times \mathrm{D}_{\mathrm{km}}$ interaction. The recoveries of the various FA were also analyzed using the model above, but including the effect of individual FA and their interaction with dietary treatment, as previously done by Cattani et al. (2014).

Because a group of cows was considered an experimental unit, the $D_{k}$ effect was always tested considering $\mathrm{G} \times \mathrm{P}_{\mathrm{ji}}(6 \mathrm{df})$ as the line of error, and orthogonal 
Table 2. Effect of diet on milk and cheese production, and on fat, protein, and TS yields $(\mathrm{n}=8)$

\begin{tabular}{|c|c|c|c|c|c|c|c|c|}
\hline Item & \multicolumn{4}{|c|}{ Diet $\operatorname{LSM}^{1}$} & SEM & \multicolumn{3}{|c|}{ Diet $P$-value ${ }^{2}$} \\
\hline \multicolumn{9}{|l|}{ Milk } \\
\hline Fat yield, $\mathrm{g} / \mathrm{d}$ & 1,050 & 914 & 982 & 901 & 24.2 & 0.14 & $<0.01$ & 0.28 \\
\hline Protein yield, $\mathrm{g} / \mathrm{d}$ & 1,012 & 1,000 & 929 & 944 & 23.4 & 0.025 & 0.94 & 0.59 \\
\hline TS yield, g/d & 3,723 & 3,582 & 3,489 & 3,503 & 74.6 & 0.07 & 0.41 & 0.32 \\
\hline Fat yield & 950 & 755 & 949 & 779 & 33.3 & 0.73 & $<0.01$ & 0.71 \\
\hline Protein yield & 713 & 680 & 648 & 661 & 19.9 & 0.08 & 0.63 & 0.29 \\
\hline TS yield & 1,864 & 1,629 & 1,771 & 1,616 & 39.5 & 0.23 & $<0.01$ & 0.35 \\
\hline
\end{tabular}

${ }^{1} \mathrm{CP} 15$ and $\mathrm{CP} 12=$ diets providing 150 or $123 \mathrm{~g}$ of $\mathrm{CP} / \mathrm{kg}$ of DM, respectively; CP $15_{\mathrm{CLA}}$ and CP12 $\mathrm{CLA}=$ diets top-dressed with $80 \mathrm{~g} / \mathrm{d}$ of a commercial mixture of rumen-protected CLA providing 5.57 and $5.40 \mathrm{~g} / \mathrm{d}$ of C18:2 cis-9,trans-11 and C18:2 trans-10, cis-12, respectively (Sila, Noale, Italy).

${ }^{2}$ The italic $P$-values indicate significant negative effects of CP reduction or CLA addition.

contrasts were run to test the effects of CP, CLA, and the $\mathrm{CP} \times \mathrm{CLA}$ interaction. All results are presented as least squares means.

\section{RESULTS}

We observed no effects of feeding treatment on milk yield, but a reduction in dietary $\mathrm{CP}$ reduced milk protein yield by $10.7 \%(P=0.025)$ and tended to reduce (by $6.0 \% ; P=0.08$ ) cheese protein yield (Table 2 ). Supplementation with CLA reduced milk fat yield by $7.0 \%(P<0.001)$ and cheese fat yield by $19.2 \%(P<$ $0.001)$. Moreover, CLA addition reduced ripened cheese yield by $10.5 \%(P=0.012)$ and cheese TS yield by $10.7 \%(P<0.001)$.

We found no effects of dietary $\mathrm{CP}$ content on the yields and relative proportions of the major FA categories (Table 3). Supplementation of CLA reduced yields in all the FA categories to varying extents ( $5 \%$ to $18 \%$ ), and as a consequence altered their relative proportions, with decreases in short-chain $(-2.7 \% ; P=0.046)$ and medium-chain $(-3.7 \% ; P<0.001) \mathrm{FA}$, an increase in long-chain FA $(+7 \% ; P<0.001)$, and a decrease in SFA $(-2.5 \% ; P<0.001)$. We observed increases in MUFA $(+5.9 \% ; P<0.001)$ and PUFA $(+7.4 \% ; P<0.001)$. Cheese manufacturing and ripening also strongly influenced FA yields, decreasing short-chain $(-19 \% ; P$ $<0.001)$ and medium-chain $(-18 \% ; P<0.001)$ FA, increasing long-chain FA $(+7.6 ; P=0.012)$, and decreasing SFA $(-15.7 \% P<0.001)$ without influencing MUFA and PUFA yields. These changes resulted in the modification of the relative proportions of all FA categories.

The yields of a large part of the even (Table 4) and odd (Table 5) SFA were reduced proportionally more by CLA supplementation than all milk fat, with a consequent reduction in their relative proportions, except for very long SFA ( $\geq 20$ carbons). A similar reduction in these FA was noted in cheese, but the yield and relative proportion of $\mathrm{C} 18: 0$ increased $(P<0.001)$.

We observed no effect of dietary CP content on the yields and proportions of even and odd SFA in milk and cheese, and no significant effect on the daily yield of branched SFA, but, because of its tendency to reduce other FA, CP increased the relative proportions of their sum and of several individual branched FA in milk (Table 6). On the other hand, the yield of branched FA was reduced by addition of rumen-protected CLA (except for C19:0 iso and C19:0 anteiso), but the proportions of total FA did not generally change. Except for a few FA, milk processing to ripened cheese decreased the yield and relative contents of all branched FA.

With a few exceptions, we observed no effects of CP on either the daily yields or proportions of short and medium MUFA (Table 7). Supply of CLA reduced the daily yield of almost all these FA, similar to overall milk fat, but in some cases (C10:1 cis-9, $\Sigma$ C12:1 isomers, $\Sigma$ C14:1 others) to a lesser extent than the rest of the FA, so that their relative proportions were increased.

Unlike previously observed trends, dietary CP and CLA supply had no effect, or only a weak effect in the case of 18:1 cis-9, on the yield and relative proportions of long-chain MUFA (Table 8). In the case of cheese manufacturing and ripening, the general trend was toward an increase in both daily yield and the relative proportions of these FA in cheese compared with milk.

The yields of the large majority of PUFA, CLA excluded (Table 9), were not altered by CP reduction but were decreased by CLA supply, although we observed no effects on the relative contents. Cheesemaking and 
MILK AND CHEESE FATTY ACIDS

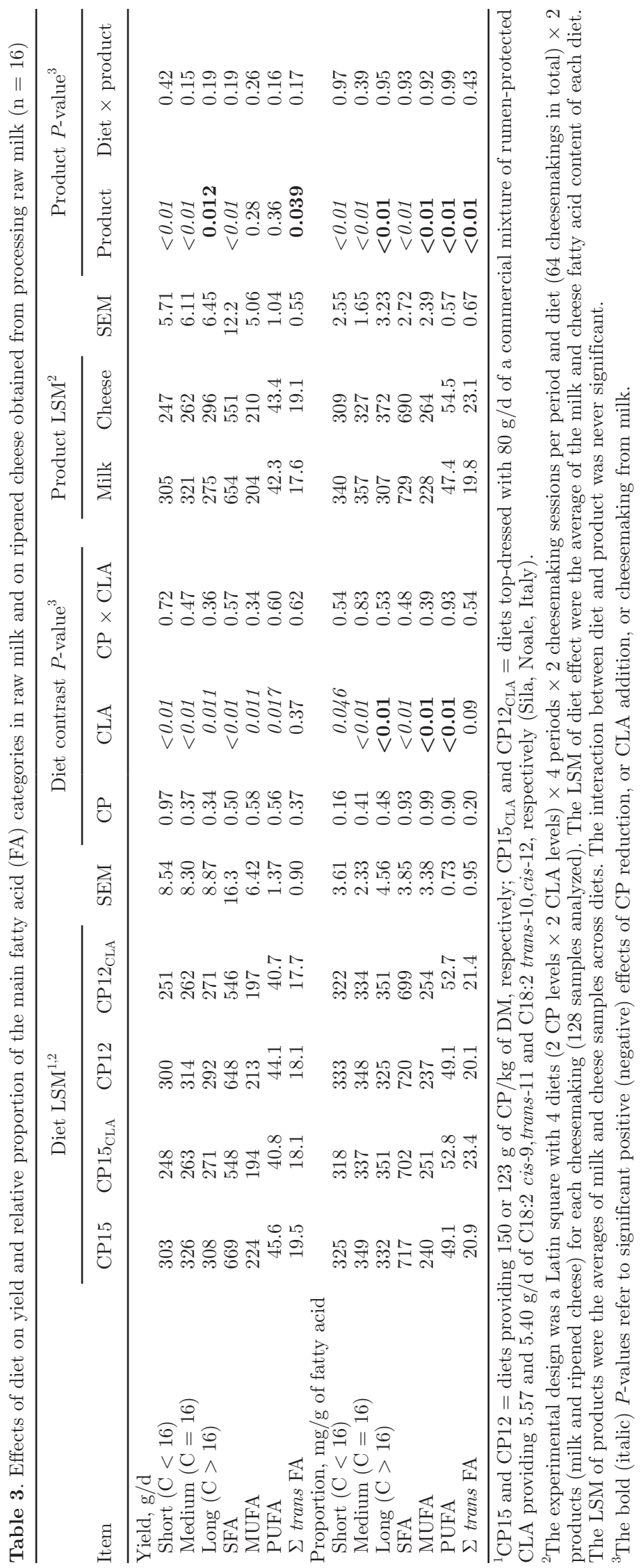


SCHIAVON ET AL.

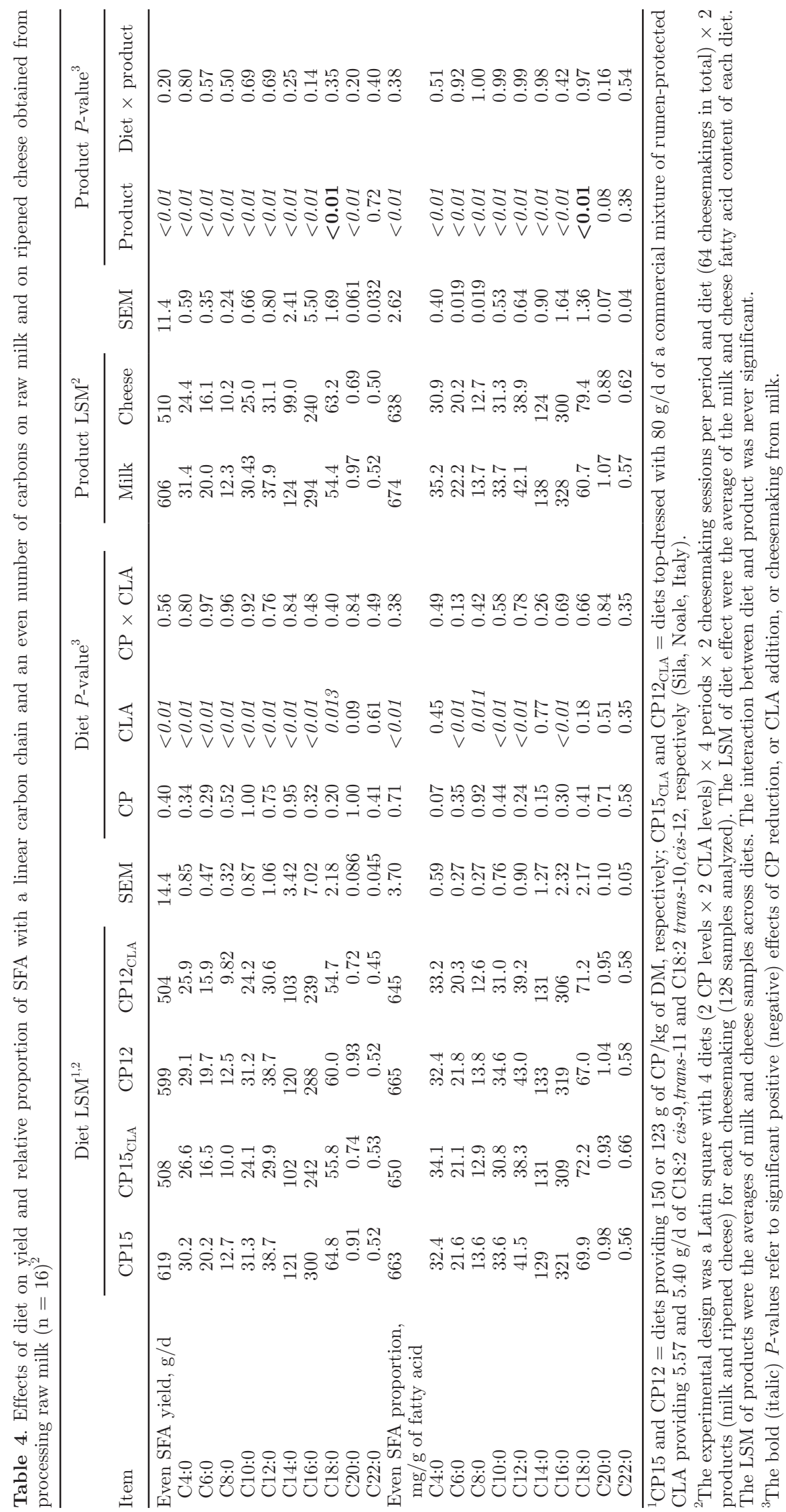


MILK AND CHEESE FATTY ACIDS

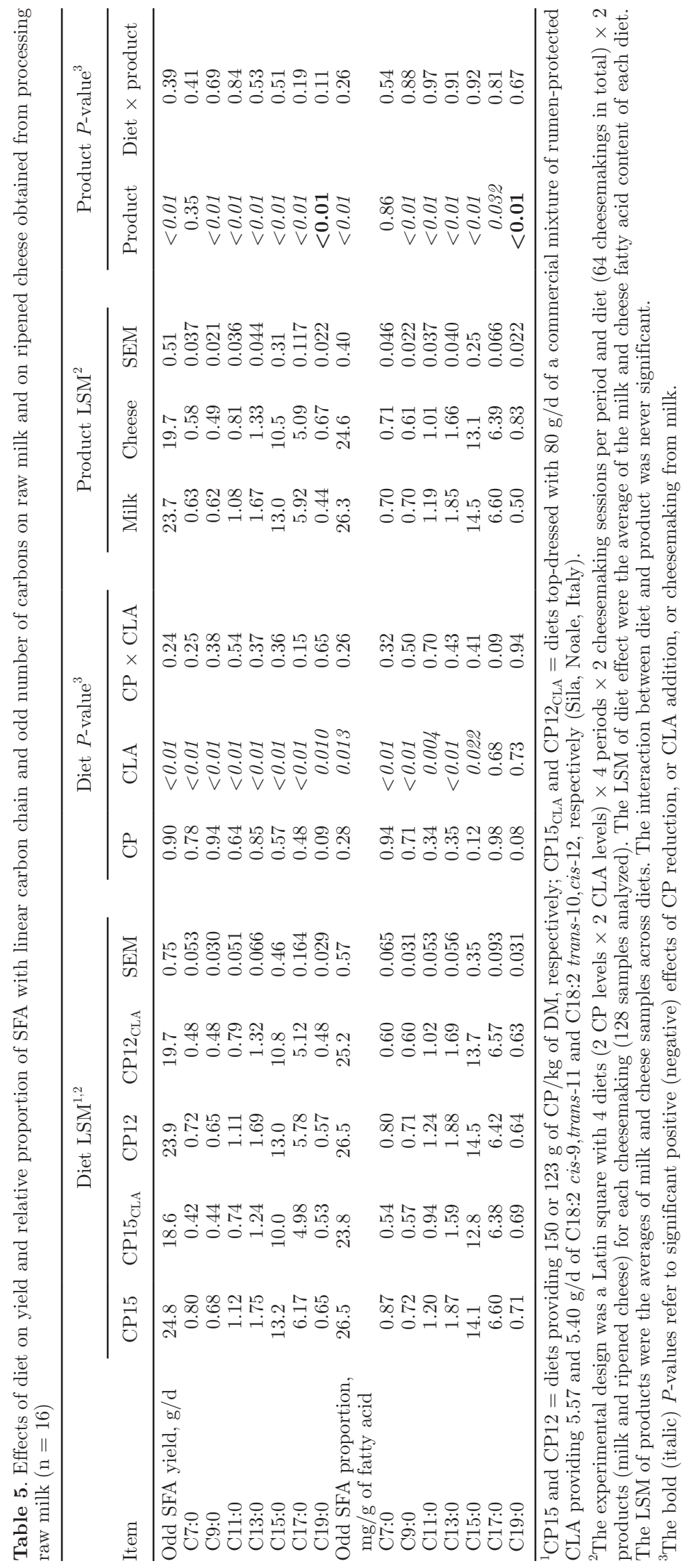




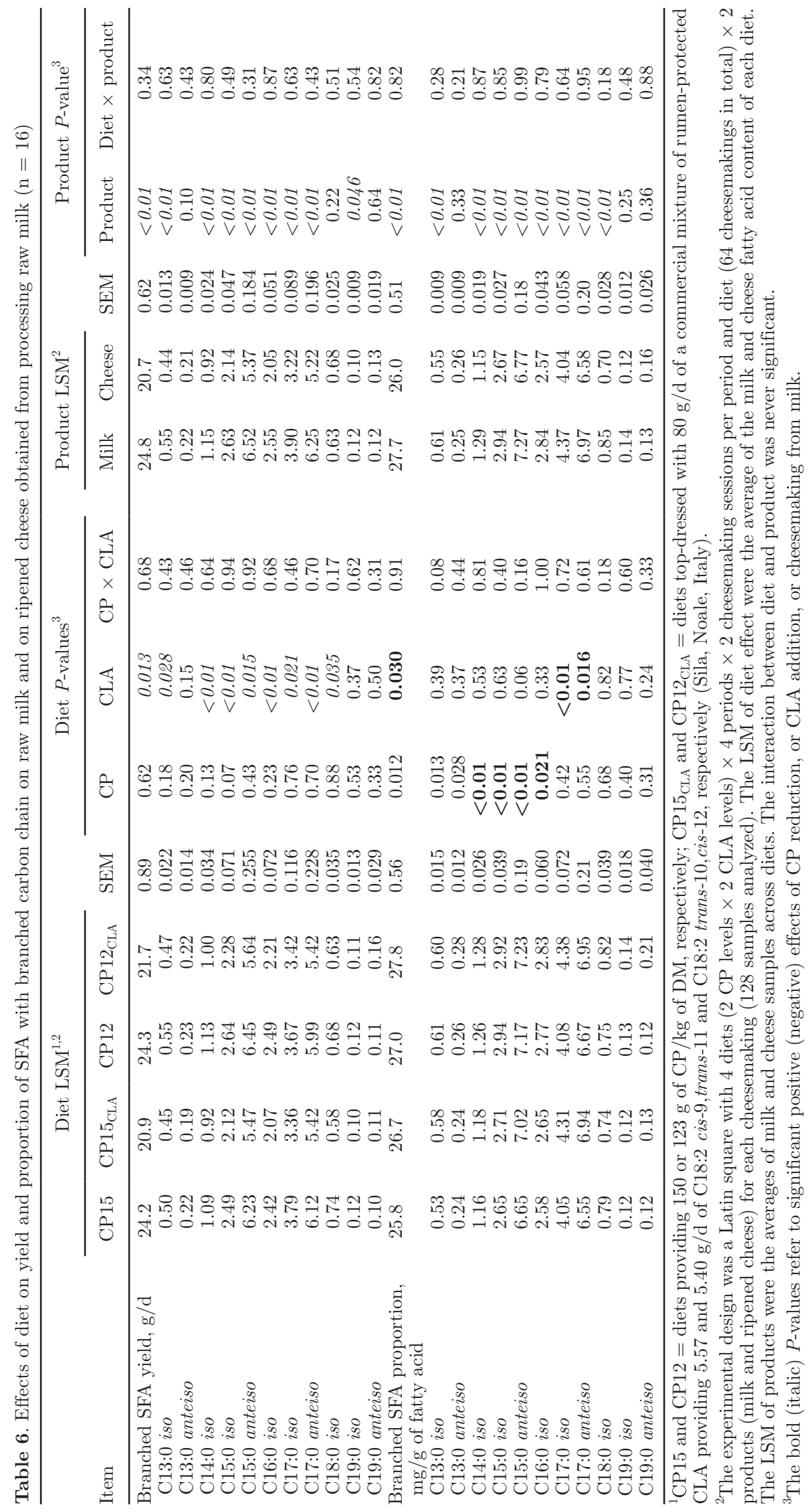




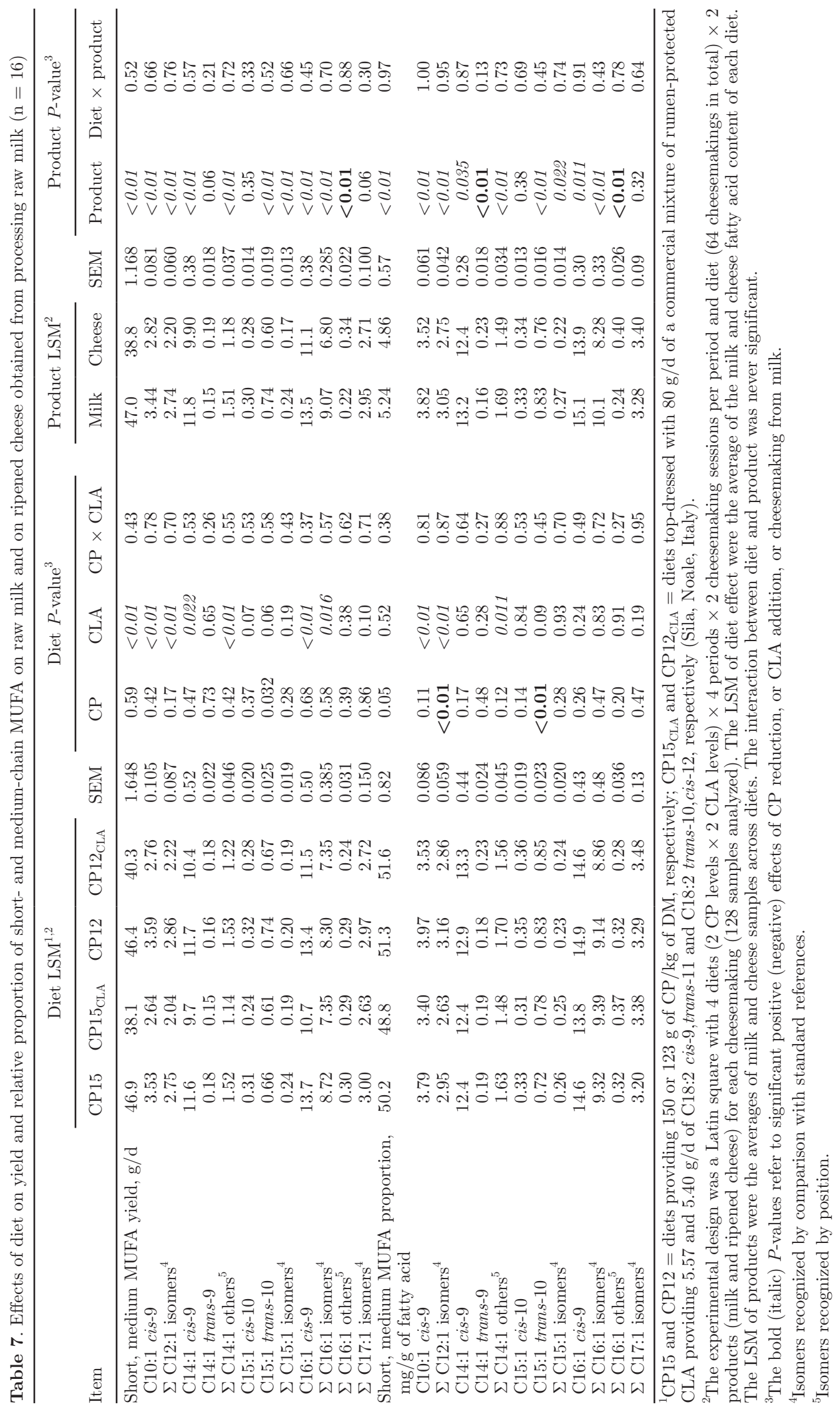




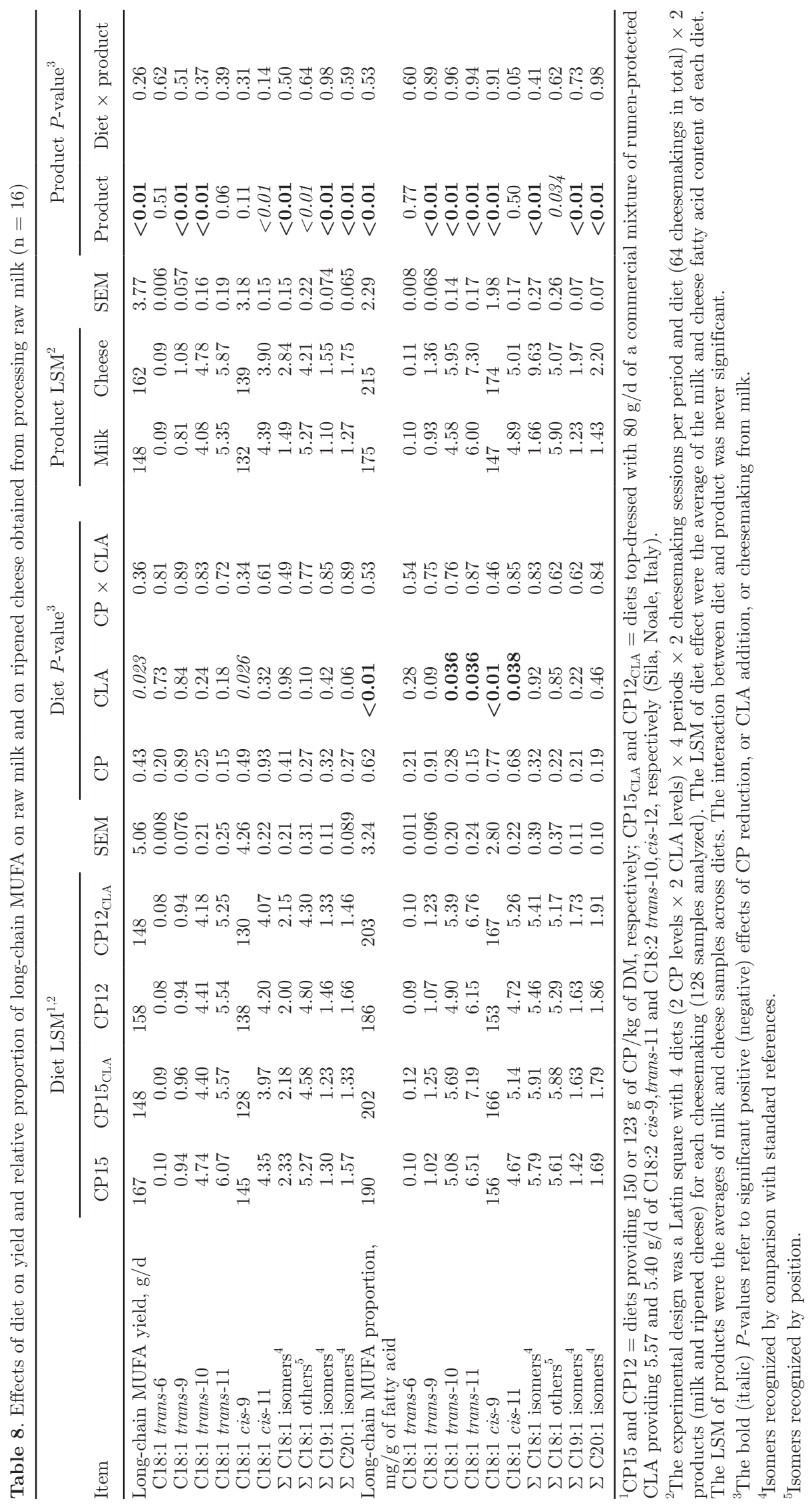




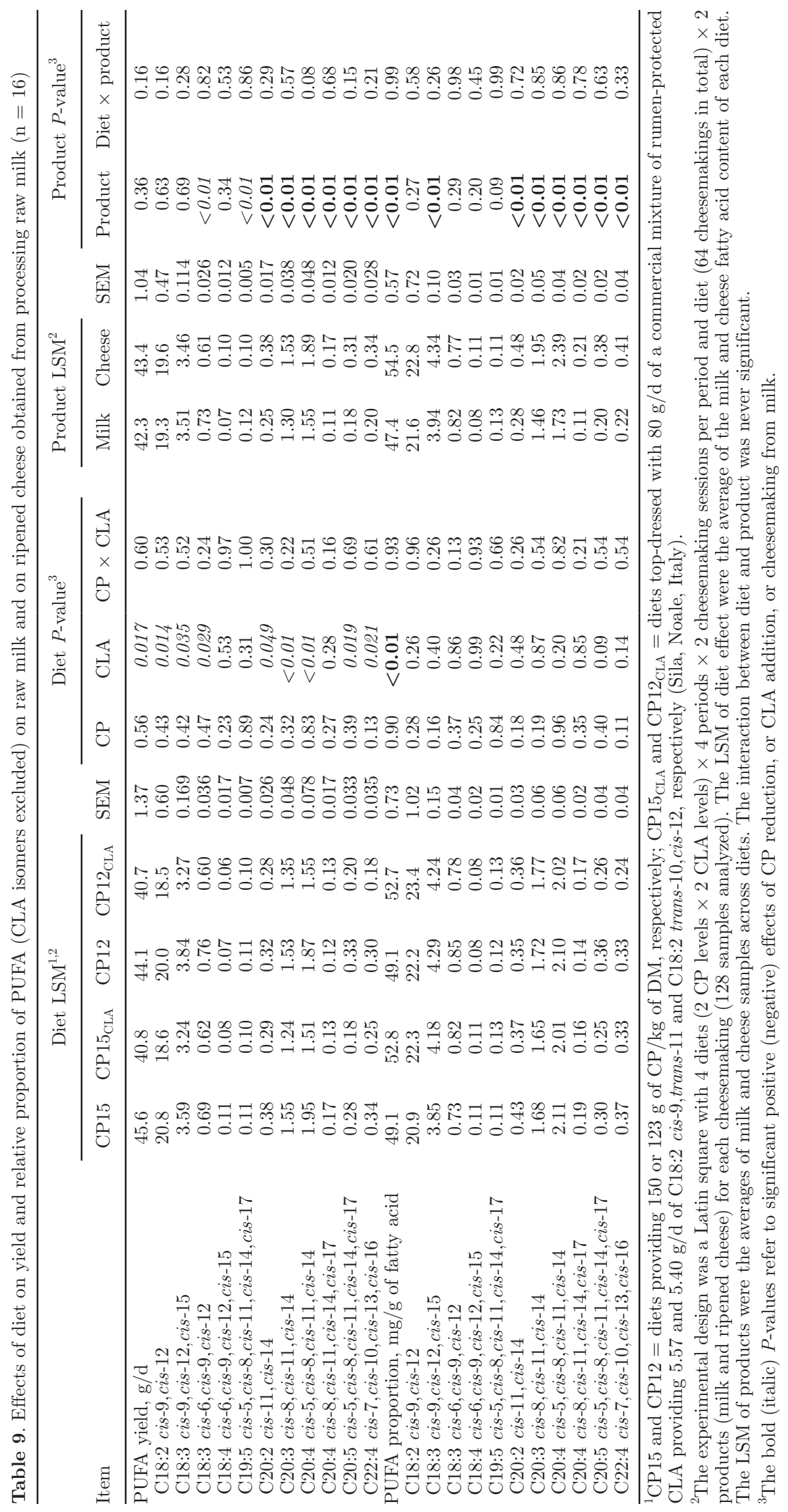


ripening had a small effect on PUFA with 18 to 19 carbon atoms, but increased the yield and relative proportions of PUFA with 20 and 22 carbon atoms.

We found no effects of dietary CP, CLA supply, and cheese manufacturing and ripening on total CLA yields in milk and cheese, but their relative contents were increased (Table 10). The 6 isomers of CLA analyzed in the present study responded differently. Supplementation with CLA increased the daily secretion and relative contents of $\mathrm{C} 18: 2$ cis-11,trans-13 and C18:2 trans9,trans-11 $(P<0.01$ and $P=0.019$, respectively $)$, but these isomers were not those present in the commercial CLA mixture (C18:2 cis-9,trans-11, C18:2 trans10,cis-12). The relative content of $\mathrm{C} 18: 2$ cis-9,trans-11 $(P<0.01)$ was increased as a consequence of CLA supply, but not the daily secretion. The other CLA isomers were not influenced by CLA supplementation. Moreover, the yields and the relative contents of 3 out of 6 CLA isomers were increased by cheesemaking and ripening.

Dietary CP content did not influence the recovery of milk fat, protein, or TS in cheese, which were in the order of 900, 700, and $500 \mathrm{mg} / \mathrm{g}$, respectively. However, CLA supplementation notably decreased $(9 \%)$ TS, fat, and SFA recovery, and tended to reduce $(P<0.10)$ the recovery of all other FA categories (Figure 1).

Apparent recovery of individual FA in cheese ranged from $63.6 \%$ for $\mathrm{C} 24: 0$ to $170.9 \%$ for $\mathrm{C} 22: 4$ cis-7, cis10,cis-13, cis-16 (Figure 2). With respect to fat recovery (900 mg/g), 34 FA (mainly SFA and short-chain FA) had recoveries $<900 \mathrm{mg} / \mathrm{g}$, and $32 \mathrm{FA}$ (mainly unsaturated and long-chain FA) had recoveries $>900 \mathrm{mg} / \mathrm{g}$.

\section{DISCUSSION}

Milk fat is composed of a large number of FA originating partly from mammary gland synthesis and partly from feeds consumed and body depots (Chilliard et al., 2000). Moate et al. (2007) showed that the currently available literature tends "to aggregate a number of closely related fatty acids under a single category," and to make a "selective reporting of only those fatty acids that are present in milk fat in appreciable quantities." In addition, in many papers the effects of a given treatment are evaluated in terms of absolute $(\mathrm{mg} / \mathrm{g}$ of milk) or relative $(\mathrm{mg} / \mathrm{g}$ of total $\mathrm{FA})$ concentrations; data are only occasionally expressed in terms of total daily FA production, or secretion, in the milk. These shortcomings tend to produce blurry pictures that only partially reflect the effects of a given treatment and make clear interpretation of the results difficult. In the present study, the effects of the various treatments on the FA profiles were evaluated over a large number of

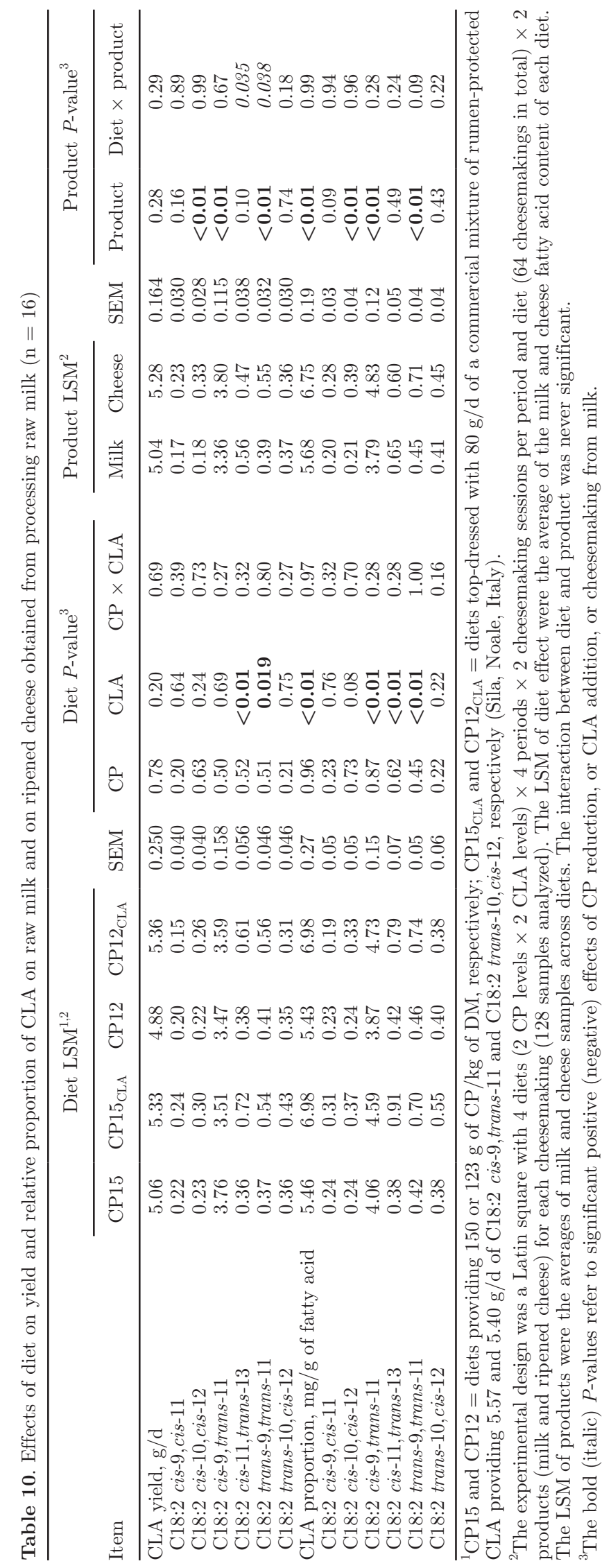


individual $\mathrm{FA}$ in terms of both relative concentrations and daily yields.

\section{Effects of Dietary Protein Reduction}

The nutritional strategy of reducing dietary $\mathrm{CP}$ to decrease $\mathrm{N}$ excretion and emissions in the environment from farm animals has gained recent interest. Besides possible environmental benefits and a reduction in feeding costs (Schiavon et al., 2015), the consequences for the quality of the product must also be evaluated
(Cesaro and Schiavon, 2015). The available literature quoted by Leonardi et al. (2003) on the effects of various levels of dietary CP (with contextual reductions of RDP and MP) on milk fat is still inconsistent, as some experiments found no effects on milk fat yield and others did find effects on milk fat content. Leonardi et al. (2003) found that a decrease in dietary CP reduced milk fat yield and increased the relative content of 18:1 trans isomers, which are considered responsible for the observed milk fat depression. Cabrita et al. (2003) and Vlaeminck et al. (2006) also found negative correla-

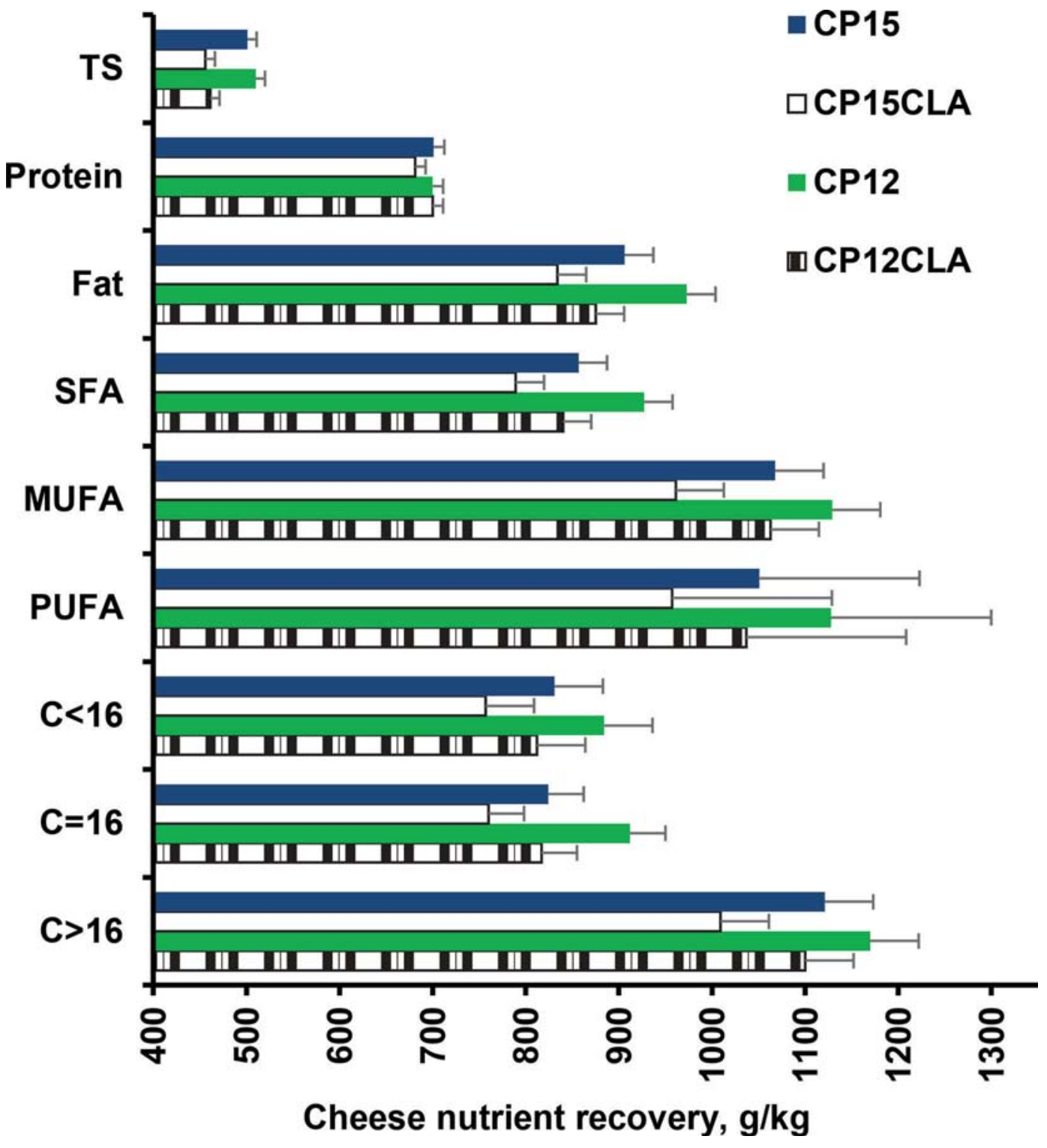

Figure 1. Effects of diet on the recovery into 90-d-ripened cheese $(\mathrm{g} / \mathrm{kg})$ of TS; protein; fat; fatty acids with short $(<16 \mathrm{C})$, medium $(16 \mathrm{C})$ or long $(>16 \mathrm{C})$ carbon chains; and on SFA, MUFA, and PUFA. Bars indicate SE $(\mathrm{n}=8)$. The effect of CLA was significant for TS $(P<0.01)$, fat $(P<0.05)$, and SFA $(P<0.05)$, and a tendency was found for other variables $(P<0.10)$. CP15 or CP12= diets providing 150 or $123 \mathrm{~g}$ of $\mathrm{CP} / \mathrm{kg}$ of DM, respectively; CLA = diets top-dressed with $80 \mathrm{~g} / \mathrm{d}$ of a commercial mixture of rumen-protected CLA providing 5.57 and $5.40 \mathrm{~g} / \mathrm{d}$ of C18:2 cis-9,trans-11 and C18:2 trans-10,cis-12, respectively (Sila, Noale, Italy). Color version available online. 


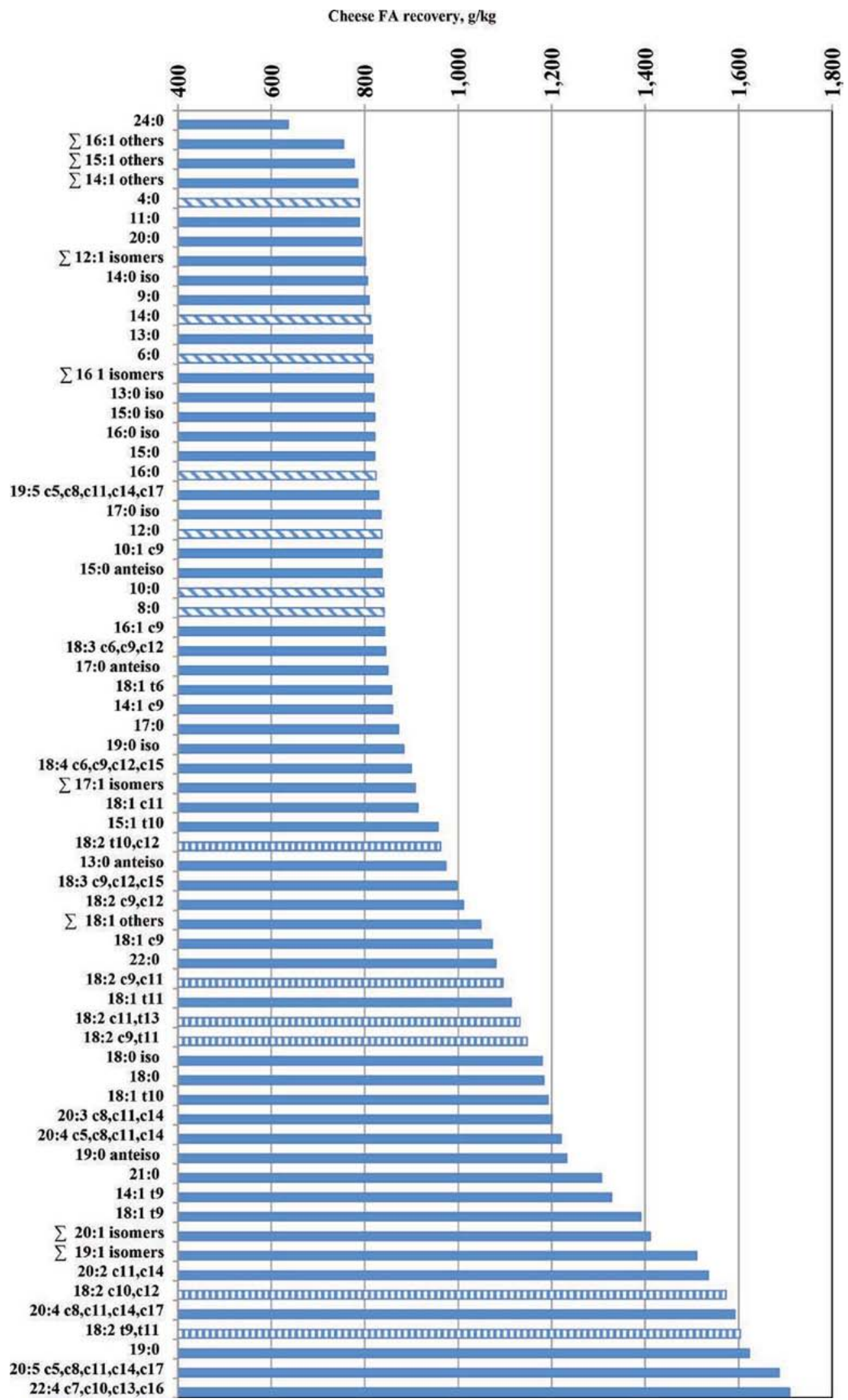

Figure 2. Mean recovery $(\mathrm{g} / \mathrm{kg})$ of individual fatty acids $(\mathrm{FA})$ in cheese after $90 \mathrm{~d}$ of ripening $(\mathrm{n}=32)$; vertical white-striped bars refer to CLA isomers; diagonal white-striped bars refer to de novo even SFA. $\mathrm{c}=$ cis; $\mathrm{t}=$ trans. Color version available online. 
tions between dietary $\mathrm{CP}$ and the relative proportions of some odd and branched FA (C17:0 anteiso, C17:0 iso, and C17:0), suggesting that these FA might be considered markers of RDP deficiency, according to the view that different microbial populations might have different contents of these FA (O'Kelly and Spiers, 1991). As well, de Veth et al. (2006) used diets with reduced amounts of MP for milk production (about $88 \%$ of MP requirements) to replicate cows in early lactation or excess amounts of MP ( $117 \%$ of MP requirements) to resemble a pasture-based system. They showed as reduction of MP supply had no effect on any of the production variables in CLA-supplemented cows, but slightly decreased the milk secretion of C18:1 trans-10, C18:1 trans-12, C18:2 cis-9,cis-12, C18:3, and C20:0 (likely caused by a contextual reduction of RDP), with no interactions between dietary MP content and CLA supplementation.

In the present study, the approximately $20 \%$ reduction in dietary $\mathrm{CP}$, RDP, and MP content influenced milk protein yield but had small or no effects on milk fat yield or on the yields and contents of the large majority of FA, including those belonging to the odd group, except C15:1 trans-10 and the C18:1 trans group. The only difference brought about by this reduction regarded an increase in the relative proportions of several branched FA with $\mathrm{C} 13$ to $\mathrm{C} 16$, confirmation that their relative proportions could be considered a marker of a RDP shortage, but we observed no effect on the daily yield of these FA, so that the increase in their relative proportions seems to be due to a slight decrease in the other linear chain FA rather than an increase in the branched FA. Taking the results of the present study together with those of the current literature, it seems likely that in many experiments the effects of dietary $\mathrm{CP}$ on milk fat components was mainly a consequence of substituting feed ingredients (e.g., soybean meal with cereals) or nutrients (protein with starch or fiber) in the ration, with possible interference in the cows' feed intake and energy balance. Therefore, a suboptimal dietary $\mathrm{CP}$ content would in itself have a weak or no effect on milk FA constituents. However, because the cows in the present study responded to a reduction in the dietary RDP content by increasing rumination time (Schiavon et al., 2015), some influences of the microbial populations in the rumen cannot be excluded.

\section{Rumen-Protected CLA Supply and Interactions with Dietary CP}

Previous research has shown that rumen-protected CLA exerts a small effect on the FA profiles of subcutaneous fat and intramuscular fat of beef cattle and lambs (Schiavon et al., 2011; Pellattiero et al., 2015a), but has a strong effect on milk fat yield and its FA profile (de Veth et al., 2006; Bauman et al., 2008). Baumgard et al. (2000) showed that milk fat yield is progressively reduced by increasing supplemental amounts of C18:2 trans-10,cis-12, and Perfield et al. (2002) found CLA reduced the FA yield of all chain lengths, but the reduction was proportionally greater with short and medium FA (de novo synthesized) than with long-chain FA. A CLA supply is commonly observed to bring about a reduction in milk fat content and an increased proportion of long-chain PUFA out of total FA (de Veth et al., 2006). These findings were confirmed by the present study, where short- and medium-chain FA yields decreased by about $18 \%$ and long-chain FA yields by only $10 \%$. We observed a lack of effect of rumenprotected CLA on the milk daily secretion of C18:2 cis9,trans-11 and C18:2 trans-10,cis-12. This result could be explained by a reduction of the $\Delta^{9}$-desaturase in the groups of animals receiving the CLA supplementation, in agreement with de Veth et al. (2006) and Sinclair et al. (2007).

The effect of CLA in combination with a low CP diet is of interest because it has been suggested that CLA exerts some protein-sparing effects (Park et al., 1997; Pariza et al., 2001; Schiavon et al., 2010). In this regard, low-protein diets and rumen-protected CLA supplementation have been found to increase nitrogen efficiency in very lean double muscle beef cattle, even though the CP $\times$ CLA interaction had few or no effects on meat composition and the FA profiles of subcutaneous fat and intramuscular fat (Schiavon et al., 2012). However, in the present study the $\mathrm{CP} \times$ CLA interaction had no effect at all on the yield of milk and milk constituents, or on the milk FA profile. Therefore, interference between dietary CP and CLA supplementation on milk FA composition and FA yield can be excluded, at least under the conditions of the present study.

\section{Cheese Manufacturing and Nutrient Recovery}

Milk protein and fat recoveries in ripened cheese averaged about 700 and $900 \mathrm{~g} / \mathrm{kg}$, respectively, in good agreement with previous research (Emmons and Modler, 2010; Bittante et al., 2013; Cecchinato et al., 2015). Protein recovery was not affected by dietary CP or by CLA addition, but CLA reduced fat recovery in cheese by $9 \%$. Few data were available on the phenotypic causes of variation in fat recovery. As described by Lucey and Kelly (1994), the 2 main factors affecting cheese yield are milk composition and cheesemaking conditions. Protein (casein) and fat concentration in milk are the most important factors, because casein forms the structural matrix containing fat and mois- 
ture, and an increase of $0.1 \%$ in the casein and fat concentration of milk results in an increase of about $0.2 \%$ of cheese yield. The concentration of milk constituents varies depending on breed, stage of lactation, season, and feeding regimen (Wedholm et al., 2006; Bland et al., 2015), as experienced in the present study, where the reduction of dietary protein tended to reduce cheese yield and fat depression due to rumen-protected CLA supplements resulted in a significant reduction of cheese yield. Fagan et al. (2007) and Cecchinato and Bittante (2016) found that fat recovery in the curd, which is important for the final cheese yield, is affected by both coagulation and syneresis, because it depends on the relative rigidity and structure of the protein network.

Interestingly, CLA supply negatively affected the milk coagulation properties of bovine and ovine milk (Bittante et al., 2014; Vacca et al., 2015). Using the same milk samples as those collected for the present study, Cesaro and Schiavon (2015) found that rumenprotected CLA supplementation increased rennet coagulation time and time to curd firmness of $20 \mathrm{~mm}$ $\left(\mathrm{k}_{20}\right)$, and reduced curd firmness 30 min after enzyme addition $\left(\mathrm{a}_{30}\right)$. The results of the present study suggest that CLA reduces the proportion of fat retained in the curd, probably because of alterations to the coagulation and syneresis processes. In addition, a decrease in fat recovery might also depend on a greater dilution of fat globules in the CLA milk compared with controls. In this regard, Banks et al. (1986) stated that differences in fat retention could to some extent be related to the overall fat content of the milk, the casein-to-fat ratio, and the distribution in the size of fat globules, but considered collectively or independently, these factors could not adequately explain the differences in fat retention. The results of the present study show that rumen-protected CLA reduced not only the milk fat content but also its transfer from milk to cheese.

When FA were grouped into categories according to degree of unsaturation or length of the carbon chain, the effects of diet on recovery of the FA categories were small, with only tendencies observed (Figure 1), and the trends were similar to those found with milk fat. This similarity suggests that retention of FA in the curd was not greatly affected by chain length or degree of unsaturation. Nevertheless, we observed great differences among individual FA, with apparent recovery values ranging from 640 to $1,710 \mathrm{~g} / \mathrm{kg}$ (Figure 2). To our knowledge, only Cattani et al. (2014) have studied the apparent recovery in cheese of individual milk FA. They stated that "the recoveries of individual fatty acid were, for the most part, not dissimilar from fat recovery, except for short-chain saturated fatty acids (from 0.38 for $\mathrm{C} 4: 0$ to 0.80 for C13:0), some long-chain satu- rated fatty acids (0.56 and 0.62 for $\mathrm{C} 20: 0$ and $\mathrm{C} 21: 0$, respectively), and for C18:3n-6 (1.65)."

With respect to the apparent recovery of fat $(900 \mathrm{~g} /$ $\mathrm{kg}$ ), in the present study we observed lower apparent recoveries mainly for short-chain SFA, and for short- and medium-chain MUFA, where greater recoveries were found principally for FA belonging to minor long-chain MUFA or PUFA. Coefficients $>900 \mathrm{~g} / \mathrm{kg}$ would reflect an increase and $<900 \mathrm{~g} / \mathrm{kg}$ would reflect a decrease in the presence of individual FA because of enzymatic and microbiological transformations during ripening (Collins et al., 2003; Buccioni et al., 2012; Laskaridis et al., 2013). Previous research has shown that for short periods of ripening, the FA profile of the cheese was similar to that of the original milk (Allred et al., 2006; Bodkowski et al., 2016). However, in agreement with the results of the present study, the FA profile of the long ripened cheeses differed from that of the original milk, as found with Parmesan (Mordenti et al., 2015), Raclette (Bocquel et al., 2016) and Feta (Laskaridis et al., 2013) cheeses, but not Emmental (Gnädig et al., 2004).

The present study also assessed the effects of cheese manufacturing and $90 \mathrm{~d}$ of ripening on the daily yield of individual milk and cheese FA. In general, cheese manufacturing caused a loss of FA related to the fat lost in whey, and the effect of ripening was related to the length and conditions of cheese conservation due to the activity of both milk native and microbiological enzymes (McSweeney and Sousa, 2000). However, the daily yields of the following FA increased: C18:0 $(+31 \%), \quad \Sigma \mathrm{C} 16: 1$ others $(+54 \%)$, some long-chain C18:1 trans and cis forms (+9.4\%), many CLA isomers $(+4.7 \%)$, and some PUFA with 20 or 22 carbons $(+54 \%$, on average). Considering the paucity of information in the literature, further studies on the consequences of feeding treatments and cheese manufacturing and ripening on the resulting FA profile of cheese are desired.

\section{CONCLUSIONS}

The results of the present study suggest that a reduction in dietary CP would have only minor effects on milk and cheese fat and corresponding FA profiles (with an increase in the proportion of mid-chain branched SFA), but some reduction in milk protein yield would also occur. Supplementation with CLA was effective in reducing milk fat and altering the yield of various FA, primarily by reducing the yields of saturated shortchain FA, the ones that are supposed to be synthesized de novo. We found no interactions between the protein and CLA components of the diets for any of the parameters considered. Supplementation with CLA reduced 
the recovery in cheese of milk fat and the main milk FA categories in similar proportions. Cheese manufacturing and ripening had significant effects on cheese FA profile, increasing the presence of long-chain PUFA and reducing the presence of $\mathrm{FA}$ with shorter chains and a greater degree of saturation with respect to the original milk FA.

\section{ACKNOWLEDGMENTS}

This study was supported by the Autonomous Province of Trento. We acknowledge SILA s.r.l. (Noale, VE, Italy) for providing the rumen-protected CLA. The authors greatly appreciate the technical assistance of the staff of the laboratory and the experimental farm.

\section{REFERENCES}

Allred, S. L., T. R. Dhiman, C. P. Brennand, R. C. Khanal, D. J. McMahon, and N. D. Luchini. 2006. Milk and cheese from cows fed calcium salts of palm and fish oil alone or in combination with soybean products. J. Dairy Sci. 89:234-248.

Angulo, J., B. Hiller, M. Olivera, L. Mahecha, D. Dannenberger, G. Nuernberg, B. Losand, and K. Nuernberg. 2012. Dietary fatty acid intervention of lactating cows simultaneously affects lipid profiles of meat and milk. J. Sci. Food Agric. 92:2968-2974.

Banks, J. M., J. L. Clapperton, D. D. Muir, and A. K. Girdler. 1986. The influence of diet and breed of cow on the efficiency of conversion of milk constituents to curd in cheese manufacture. J. Sci. Food Agric. 37:461-468.

Bauman, D. E., J. W. Perfield, K. J. Harvatine, and L. H. Baumgard. 2008. Regulation of fat synthesis by conjugated linoleic acid: Lactation and the ruminant model. J. Nutr. 138:403-409.

Baumgard, L. H., B. A. Corl, D. A. Dwyer, A. Sæbø, and D. E. Bauman. 2000. Identification of the conjugated linoleic acid isomer that inhibits milk fat synthesis. Am. J. Physiol. Regul. Integr. Comp. Physiol. 278:R179-R184.

Bittante, G., C. Cipolat-Gotet, and A. Cecchinato. 2013. Genetic parameters of different measures of cheese yield and milk nutrient recovery from an individual model cheese-manufacturing process. J. Dairy Sci. 96:7966-7979.

Bittante, G., E. Pellattiero, F. Malchiodi, C. Cipolat-Gotet, M. Pazzola, G. M. Vacca, S. Schiavon, and A. Cecchinato. 2014. Quality traits and modelling of coagulation, curd firming, and syneresis of sheep milk of Alpine breeds fed diets supplemented with rumenprotected conjugated fatty acid. J. Dairy Sci. 97:4018-4028.

Bland, J. H., A. S. Grandison, and C. C. Fagan. 2015. Effect of blending Jersey and Holstein-Friesian milk on Cheddar cheese processing, composition, and quality. J. Dairy Sci. 98:1-8.

Bocquel, D., R. Marquis, M. Dromard, P. A. Salamin, J. Rey-Siggen, J. Héritier, A. Kosinska-Cagnazzo, and W. Andlauer. 2016. Effect of flaxseed supplementation of dairy cows' forage on physicochemical characteristic of milk and Raclette cheese. Int. J. Dairy Technol. 69:129-136.

Bodkowski, R., K. Czyż, R. Kupczyński, B. Patkowska-Sokoła, P. Nowakowski, and A. Wiliczkiewicz. 2016. Lipid complex effect on fatty acid profile and chemical composition of cow milk and cheese. J. Dairy Sci. 99:57-67.

Buccioni, A., S Minieri, G. Conte, D. Benvenuti, A. Pezzati, M. Antongiovanni, S Rapaccini, and M. Mele. 2012. Changes in conjugated linoleic acid and C18:1 isomers profile during ripening of Pecorino Toscano cheese produced with raw milk. Ital. J. Anim. Sci. 11:426-430.

Cabrita, A. R. J., R. J. B. Bessa, S. P. Alves, R. J. Dewhurst, and A. J. M. Fonseca. 2007. Effects of dietary protein and starch on intake, milk production, and milk fatty acid profiles of dairy cows fed corn silage-based diets. J. Dairy Sci. 90:1429-1439.

Cabrita, A. R. J., A. J. M. Fonseca, R. J. Dewhurst, and E. Gomes. 2003. Nitrogen supplementation of corn silages. 2. Assessing rumen function using fatty acid profiles of bovine milk. J. Dairy Sci. 86:4020-4032.

Cattani, M., R. Mantovani, S. Schiavon, G. Bittante, and L. Bailoni. 2014. Recovery of $n-3$ polyunsaturated fatty acids and conjugated linoleic acids in ripened cheese obtained from milk of cows fed different levels of extruded flaxseed. J. Dairy Sci. 97:123-135.

Cecchinato, A., A. Albera, C. Cipolat-Gotet, A. Ferragina, and G. Bittante. 2015. Genetic parameters of cheese yield and curd nutrient recovery or whey loss traits predicted using Fourier-transform infrared spectroscopy of samples collected during milk recording on Holstein, Brown Swiss, and Simmental dairy cows. J. Dairy Sci. 98:4914-4927.

Cecchinato, A., and G. Bittante. 2016. Genetic and environmental relationships of different measures of individual cheese yield and curd nutrients recovery with coagulation properties of bovine milk. J. Dairy Sci. 99:1975-1989.

Cesaro, G., and S. Schiavon. 2015. Effect of protein shortage and conjugated linoleic acid supplementation on quality traits and modelling of coagulation, curd firming and syneresis of Holstein-Friesian milk. Poljoprivreda/Agriculture. 21(Suppl.):78-85.

Cesaro, G., F. Tagliapietra, L. Grigoletto, A. Cecchinato, D. Dannenberger, G. Bittante, and S. Schiavon. 2013. Fecal sample preparation methods for gas chromatography analysis of fatty acids of ruminants fed different amounts of rumen protected conjugated linoleic acids (CLA). Anim. Feed Sci. Technol. 183:184-194.

Chilliard, Y., A. Ferlay, R. M. Mansbridge, and M. Doreau. 2000. Ruminant milk fat plasticity: nutritional control of saturated, polyunsaturated, trans and conjugated fatty acids. Ann. Zootech. 49:181-205.

Chouinard, P. Y., L. Corneau, D. M. Barbano, L. E. Metzger, and D. E. Bauman. 1999. Conjugated linoleic acids alter milk fatty acid composition and inhibit milk fat secretion in dairy cows. J. Nutr. 129:1579-1584.

Collins, Y. F., P. L. H. McSweeney, and M. G. Wilkinson. 2003. Lipolysis and free fatty acid catabolism in cheese: A review of current knowledge. Int. Dairy J. 13:841-866.

Colombari, G., G. Borreani, and G. M. Crovetto. 2001. Effect of ensiling alfalfa at low and high dry matter on production of milk used to make Grana cheese. J. Dairy Sci. 84:2494-2502.

de Veth, M. J., E. Castaneda-Gutierrez, D. A. Dwyer, A. M. Pfeiffer, D. E. Putnam, and D. E. Bauman. 2006. Response to conjugated linoleic acid in dairy cows differing in energy and protein status. J. Dairy Sci. 89:4620-4631.

Emmons, D. B., and H. W. Modler. 2010. Invited review: A commentary on predictive cheese yield formulas. J. Dairy Sci. 93:55175537.

Fagan, C. C., M. Castillo, F. A. Payne, C. P. O'Donnel, and J. O'Callaghan. 2007. Effect of cutting time, temperature, and calcium on curd moisture, whey fat losses, and curd yield by response surface methodology. J. Dairy Sci. 90:4499-4512.

Glasser, F., M. Doreau, A. Ferlay, and Y. Chilliard. 2007. Technical note: Estimation of milk fatty acid yield from milk fat data. J. Dairy Sci. 90:2302-2304.

Gnädig, S., J. F. Chamba, E. Perreard, S. Chappaz, J. M. Chardigny, R. Rickert, H. Steinhart, and J. L. Sébédio. 2004. Influence of manufacturing conditions on the conjugated linoleic acid content and the isomer composition in ripened French Emmental cheese. J. Dairy Res. 71:367-371.

Griinari, J. M., D. A. Dwyer, M. A. McGuire, D. E. Bauman, D. L. Palmquist, and K. V. V. Nurmela. 1998. Trans-octadecenoic acids and milk fat depression in lactating cows. J. Dairy Sci. 81:12511261.

Hara, A., and N. S. Radin. 1978. Lipid extraction of tissues with a low-toxicity solvent. Anal. Biochem. 90:420-426.

IDF (International Dairy Federation). 2015. The World Dairy Situation. Bulletin 481/2015. International Dairy Federation, Brussels, Belgium. 
IDF (International Dairy Federation). 2000. International IDF Standard 141C:2000: Determination of milk fat, protein and lactose content-Guidance on the operation of mid-infrared instruments. International Dairy Federation, Brussels, Belgium.

ISO (International Organization for Standardization). 2001. ISO 14156: Milk and Milk Products-Extraction methods for lipids and liposoluble compounds. International Organization for Standardization, Geneva, Switzerland.

ISO (International Organization for Standardization). 2006. Milk products-Guidelines for the application of near infrared spectrometry. International Organization for Standardization, Geneva, Switzerland.

Jenkins, T. C. 2010. Technical note: Common analytical errors yielding inaccurate results during analysis of fatty acids in feed and digesta samples. J. Dairy Sci. 93:1170-1174.

Kebreab, E., J. France, J. A. N. Mills, R. Allison, and J. Dijkstra. 2002. A dynamic model of $\mathrm{N}$ metabolism in the lactating dairy cow and an assessment of impact of $\mathrm{N}$ excretion on the environment. J. Anim. Sci. 80:248-259.

Larsen, M. K., M. R. Weisbjerg, C. B. Kristensen, and G. Mortensen 2012. Short communication: Within-day variation in fatty acid composition of milk from cows in an automatic milking system. J. Dairy Sci. 95:5608-5611.

Laskaridis, K., A. Serafeimidou, S. Zlatanos, E. Gylou, E. Kontorepanidou, and A. Sagredos. 2013. Changes in fatty acid profile of feta cheese including conjugated linoleic acid. J. Sci. Food Agric. 93:2130-2136.

Leonardi, C., M. Stevenson, and L. E. Armentano. 2003. Effect of two levels of crude protein and methionine supplementation on performance of dairy cows. J. Dairy Sci. 86:4033-4042.

Lucey, J., and J. Kelly. 1994. Cheese yield. Int. J. Dairy Technol. 47:1-14.

McSweeney, P. L., and M. J. Sousa. 2000. Biochemical pathways for the production of flavor compounds in cheeses during ripening: A review. Lait 80:293-324.

Moate, P. J., W. Chalupa, R. C. Boston, and I. J. Lean. 2007. Milk fatty acids. I. Variation in the concentration of individual fatty acids in bovine milk. J. Dairy Sci. 90:4730-4739.

Mordenti, A. L., N. Brogna, F. Merendi, G. Canestrari, M. Dall'Olio, G. Biagi, and A. Formigoni. 2015. Effect of feeding whole soybean and linseed on milk and parmigiano reggiano cheese lipid fraction. Prog. Nutr. 17:220-230.

NRC. 2001. Nutrient Requirements of Dairy Cattle. 7th rev. ed. Natl. Acad. Press, Washington, DC.

O'Kelly, J. C., and W. G. Spiers. 1991. Influence of host diet on the concentrations of fatty acids in rumen bacteria from cattle. Crop Pasture Sci. 42:243-252.

Pariza, M. W., Y. Park, and M. E. Cook. 2001. The biologically active isomers of conjugated linoleic acid. Prog. Lipid Res. 40:283-298.

Park, Y., K. J. Albright, W. Liu, J. M. Storkson, M. E. Cook, and M. W. Pariza. 1997. Effect of conjugated linoleic acid on body composition in mice. Lipids 32:853-858.

Pellattiero, E., A. Cecchinato, F. Tagliapietra, S. Schiavon, and G. Bittante. 2015a. The use of 2-dimensional gas chromatography to investigate the effect of rumen-protected conjugated linoleic acid breed, and lactation stage on the fatty acid profile of sheep milk. J. Dairy Sci. 98:2088-2102.

Pellattiero, E., A. Cecchinato, F. Tagliapietra, S. Schiavon, and G. Bittante. 2015b. Determination by $\mathrm{GC} \times \mathrm{GC}$ of fatty acid and conjugated linoleic acid (CLA) isomer profiles in six selected tissues of lambs fed on pasture or on indoor diets with and without rumen-protected CLA. J. Agric. Food Chem. 63:963-974.

Perfield, J. W., II, G. Bernal-Santos, T. R. Overton, and D. E. Bauman. 2002. Effects of dietary supplementation of rumen-protected conjugated linoleic acid in dairy cows during established lactation. J. Dairy Sci. 85:2609-2617.

Schiavon, S., G. Cesaro, F. Tagliapietra, L. Gallo, and G. Bittante. 2015. Influence of $\mathrm{N}$ shortage and conjugated linoleic acid supplementation on some productive, digestive, and metabolic parameters of lactating cows. Anim. Feed Sci. Technol. 208:86-97.

Schiavon, S., M. De Marchi, F. Tagliapietra, L. Bailoni, A. Cecchinato, and G. Bittante. 2011. Effect of high or low protein ration combined or not with rumen protected conjugated linoleic acid (CLA) on meat CLA content and quality traits of double-muscled Piemontese bulls. Meat Sci. 89:133-142.

Schiavon, S., E. Pellattiero, A. Cecchinato, F. Tagliapietra, D. Dannenberger, K. Nuernberg, and G. Bittante. 2016. The influence of different sample preparation procedures on the determination of fatty acid profiles of beef subcutaneous fat, liver and muscle by gas chromatography. J. Food Compos. Anal. 50:10-18.

Schiavon, S., F. Tagliapietra, M. Dal Maso, L. Bailoni, and G. Bittante. 2010. Effects of low-protein diets and rumen-protected conjugated linoleic acid on production and carcass traits of growing double-muscled Piemontese bulls. J. Anim. Sci. 88:3372-3383.

Schiavon, S., F. Tagliapietra, G. Dalla Montà, A. Cecchinato, and G. Bittante. 2012. Low protein diets and rumen-protected conjugated linoleic acid increase nitrogen efficiency and reduce the environmental impact of double-muscled young Piemontese bulls. Anim. Feed Sci. Technol. 174:96-107.

Shingfield, K. J., L. Bernard, C. Leroux, and Y. Chilliard. 2010. Role of trans fatty acids in the nutritional regulation of mammary lipogenesis in ruminants. Animal 4:1140-1166.

Sinclair, L. A., A. L. Lock, R. Early, and D. E. Bauman. 2007. Effects of trans-10, cis-12 conjugated linoleic acid on ovine milk fat synthesis and cheese properties. J. Dairy Sci. 90:3326-3335.

Vacca, G. M., M. Pazzola, M. L. Dettori, E. Pira, F. Malchiodi, C. Cipolat-Gotet, A. Cecchinato, and G. Bittante. 2015. Modeling of coagulation, curd firming, and syneresis of milk from Sarda ewes. J. Dairy Sci. 98:2245-2259.

Vlaeminck, B., V. Fievez, A. R. J. Cabrita, A. J. M. Fonseca, and R. J. Dewhurst. 2006. Factors affecting odd-and branched-chain fatty acids in milk: A review. Anim. Feed Sci. Technol. 131:389-417.

Wedholm, A., L. B. Larsen, H. Lindmark-Månsson, A. H. Karlsson, and A. Andrén. 2006. Effect of protein composition on the cheesemaking properties of milk from individual dairy cows. J. Dairy Sci. 89:3296-3305. 